\title{
Protective Effect of Combined Long Time Administration of Selenium and Vitamin C on Liver and Kidney Toxicity of Cadmium in Rats
}

\author{
Mohammad Mahdi Zamani ${ }^{1,2,3}$ (D), Seyedeh Hamideh Mortazavi ${ }^{3}$ (D), Maryam Monajjemzadeh ${ }^{4}$ (D), \\ Vahhab Piranfar $^{5}$, Zahra Aalidaeijavadi ${ }^{3}$, Azam Bakhtiarian ${ }^{6 *}$ (D)
}

\author{
1. Exceptional Talent Development Center (EDTC), Tehran University of Medical Sciences, Tehran, Iran \\ 2. Department of Anesthesiology and Critical Care, Hasheminejad Kidney Center (HKC), Iran University of Medical Sciences, Tehran, Iran \\ 3. Scientific Students' Research Center, Tehran University of Medical Sciences, Tehran, Iran \\ 4. Department of Pathology, School of Medicine, Tehran University of Medical Sciences, Tehran, Iran \\ 5. Department of Medical Microbiology, School of Medicine, Iran University of Medical Science, Tehran, Iran \\ 6. Department of Pharmacology, School of Medicine, Tehran University of Medical Sciences, Tehran, Iran
}

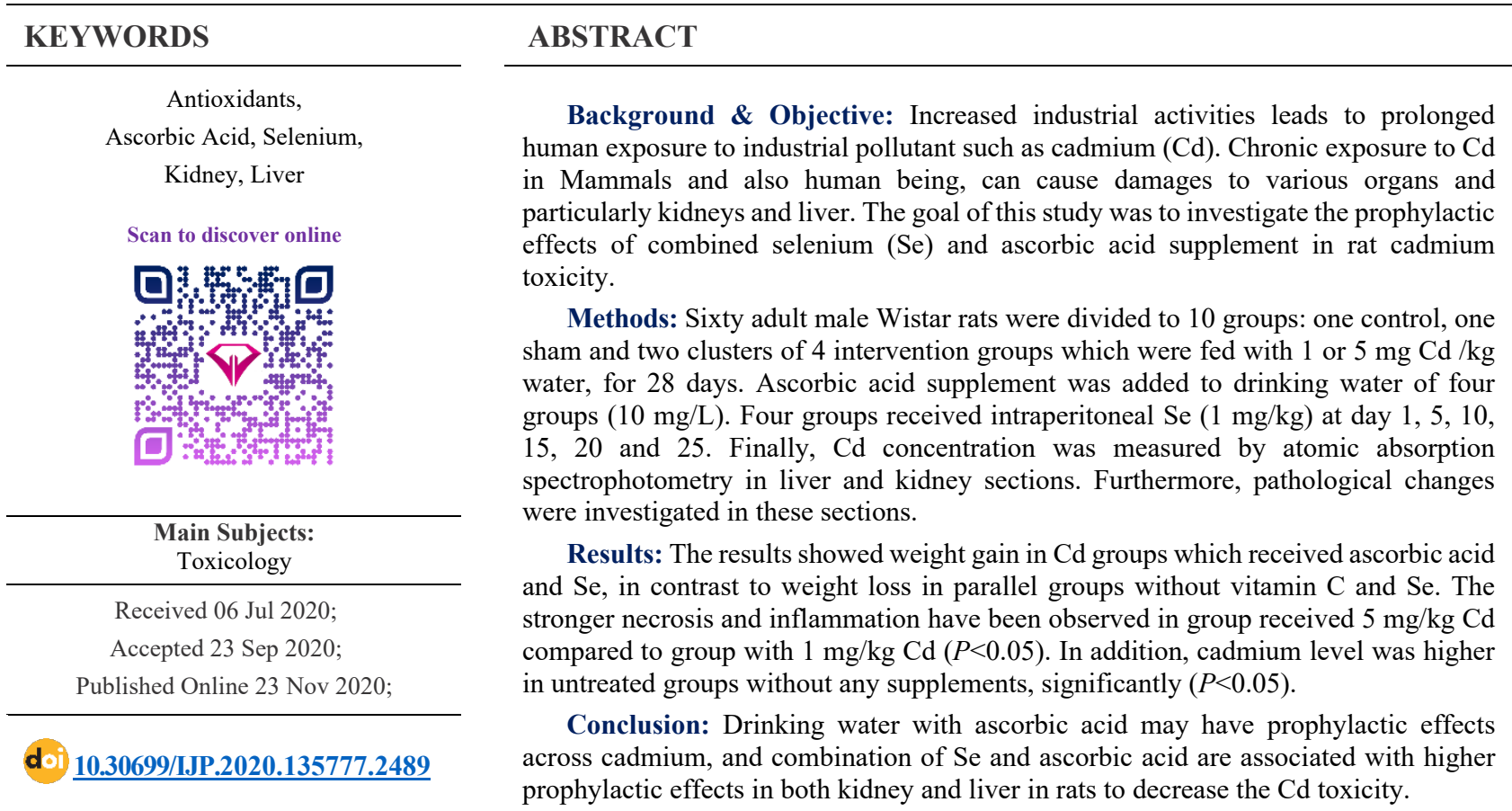

\begin{tabular}{ll}
\hline Corresponding Information: & Azam Bakhtiarian, Department of Pharmacology, School of Medicine, Tehran University of Medical Sciences, \\
& Tehran, Iran Email: bakhtiar@sina.tums.ac.ir
\end{tabular}

Copyright $(C)$ 2021. This is an open-access article distributed under the terms of the Creative Commons Attribution- 4.0 International License which permits Share, copy and redistribution of the material in any medium or format or adapt, remix, transform, and build upon the material for any purpose, even commercially.

\section{Introduction}

During recent years, industrial activities have been increased which leads to prolonged human exposure to industrial pollutant such as cadmium $(\mathrm{Cd})$, which is used in batteries, pigments, plastic, electroplating, galvanism, refinery and petrochemical industries, and also arises from cigarette smoke (1-2). In addition, absorption of $\mathrm{Cd}$ in plants and animal's tissues is another way for human to get exposed with this pollutant. Because of genetic and epigenetic effects of $\mathrm{Cd}$ induced toxicity, bioindicators are under study for low levels of $\mathrm{Cd}$ as a water pollution (3).

Chronic exposure to $\mathrm{Cd}$ in human can cause damages to various organs such as lung, gastrointestinal, neurologic system, testis, immune system, endocrine and particularly kidneys and liver (4). Additionally, Cd can be carcinogen and also causes oxidation injuries in blood and other tissues which leads to cellular membrane dysfunction (5). Recent studies indicate that $\mathrm{Cd}$ can induce various genetic and epigenetic changes in plants and mammalian cells, both in vitro and in vivo (6).

Chronic exposure to $\mathrm{Cd}$ often leads to kidneys dysfunction. The first nephrotoxic effect of $\mathrm{Cd}$ is increasing low molecular weight proteinuria (7). Seventy percent of filtrated $\mathrm{Cd}$ will be absorbed in proximal tubules and it will be concentrated in cortex which causes kidney dysfunction (8) and in addition, tubular injuries are less expected (9). Groten et al. has shown that urinary enzymes (Lactate dehydrogenase, Alkaline phopsphatase and N-acetyl-beta-D-glucosaminidase) will increase after 10 month exposure to $\mathrm{Cd}(10)$. 
Liver is the next important target organ for $\mathrm{Cd}$ toxicity. After chronic $\mathrm{Cd}$ exposure of liver, increase of lipid peroxidation and changes of essential elements have been shown. In addition, $\mathrm{Cd}$ can disturb cellular respiration in liver (11). Thus, different pathologic changes in hepatocytes have been shown due to $\mathrm{Cd}$ toxicity which is distinguished with granulomatous inflammation, cellular reproduction, nodular hyperplasia, apoptosis and necrosis. The morphologic changes arise after rising serum level of liver enzymes such as alanine aminotransferase (ALT), aspartate aminotransferase (AST) (12).

Different supplements have been used in various studies to adjust or compare with $\mathrm{Cd}$ toxicity. Ascorbic acid (Vitamin C) (13), vitamin E (14), aspirin (15) and zinc (5) have antioxidant characteristic and exert their preventive effect in a tissue with reduction of oxidative pressure. It is suggested that coenzyme Q10 and vitamin E play preventive role against the $\mathrm{Cd}$ exerted change in antioxidant defense system of the body (16). The next preventive substance is the beta-carotene which is used to adjust harmful effects of $\mathrm{CdCl}$ (2) in blood hematology and semen quality. This substance by itself or in combination with vitamin E could significantly reduce toxicity of $\mathrm{Cd}$ (17). Melatonin is another substance which is mentioned in several studies as modulation of Cd toxicity (4). Additionally, calcium suggested the modulatory effect of $\mathrm{Cd}$ induced toxicity (18). Furthermore, quercetin is proposed as preventive substance against kidney toxicity caused by $\mathrm{Cd}(9)$. It is also demonstrated that vitamin $\mathrm{C}$ reduces the accumulation of $\mathrm{Cd}$ in the tissue and thereby, it could exert advantageous effect due to the major accumulation of $\mathrm{Cd}$ in liver and kidney (19). Selenium (Se) is another essential element which its deficiency correlates with increase of lipid peroxidation in order to affect the function of the cell or its membrane (8).

This study is aimed to investigate the effect of long term administration of combined $\mathrm{Se}$ and vitamin $\mathrm{C}$ treatment on prevention, reduction or adjustment of the chronic $\mathrm{Cd}$ induced toxicity in kidney and liver in rates.

\section{Materials and Methods}

\section{Animals}

In this study, 60 adult male Wistar rats with primary weight of $140 \pm 15 \mathrm{~g}$, were used. All the rats were maintained in an environment of $12 \mathrm{~h} \mathrm{light} / 12 \mathrm{~h}$ dark in the room temperature $(22 \pm 3)$ with pellet rat diet.

\section{Experimental Design}

One week prior to starting of the experiment, rats were weighed precisely (initial body weight). Then, the rats were randomly divided into 10 groups of six rats.

The control group, got $1 \mathrm{~mL}$ sterile distilled water via gavage every other day and sham group, received $1 \mathrm{~mL}$ sterile distilled water via gavage every other day, accompanied by intraperitoneal (i.p.) injection of normal saline $(1 \mathrm{cc} / \mathrm{kg})$ for six times at the day $1,5,10,15,20$ and 25 with access to Tao drinking water.

Supplemented drinking water was prepared with 10 $\mathrm{mg} / \mathrm{L}$ of vitamin $\mathrm{C}$, and $\mathrm{Se}(1 \mathrm{mg} / \mathrm{kg})$ was administered via intraperitoneal injection for six times, during experiment, at the day $1,5,10,15,20$ and 25 .

The rats of the eight experimental groups for 4 weeks, were exposed to: group 1 to 4 received $1 \mathrm{mg} / \mathrm{kg}$ cadmium chloride $(\mathrm{CdCl}(2))$ in $1 \mathrm{~mL}$ sterile distilled water via gavage every other day, and group 1 exposed to Tao drinking water $(1 \mathrm{mg} / \mathrm{kg} \mathrm{Cd})$. Group 2 exposed to supplemented drinking water $(1 \mathrm{mg} / \mathrm{kg} \mathrm{Cd}+$ supplemented water). Group 3 exposed to $\mathrm{Se}(1 \mathrm{mg} \mathrm{Cd}$ $/ \mathrm{kg}+1 \mathrm{mg} \mathrm{Se} / \mathrm{kg}$, i.p.). Group 4 exposed to both supplemented drinking water and $\mathrm{Se}(1 \mathrm{mg} \mathrm{Cd} / \mathrm{kg}+1$ $\mathrm{mg} \mathrm{Se} / \mathrm{kg}$, i.p. + supplemented water).

Group 5 to 8 received $5 \mathrm{mg} / \mathrm{kg} \operatorname{CdCl}(2)$ in $1 \mathrm{~mL}$ sterile distilled water, via gavage every other day, and group 5 exposed to Tao drinking water $(5 \mathrm{mg} \mathrm{Cd} / \mathrm{kg})$. Group 6 exposed to supplemented drinking water $(5 \mathrm{mg}$ $\mathrm{Cd} / \mathrm{kg}+$ supplemented water). Group 7 exposed to $\mathrm{Se}(5$ $\mathrm{mg} \mathrm{Cd} / \mathrm{kg}+1 \mathrm{mg} \mathrm{Se} / \mathrm{kg} \mathrm{Se}$, i.p.), and group 8 exposed to supplemented drinking water and $\mathrm{Se}(5 \mathrm{mg} \mathrm{Cd} / \mathrm{kg}+1$ $\mathrm{mg} \mathrm{Se} / \mathrm{kg}$, i.p. + supplemented water).

\section{Laboratory Assessment}

After 24 hours from ending the interventions, rats were weighed. Then, rats were sacrificed in standard situation with inhalation of chloroform and their liver and left kidney were excised.

Concentration of $\mathrm{Cd}$ in the liver and left kidney was determined by atomic absorption spectrophotometry (AAS) using a 400 SOUARES EUROMEX spectrophotometer (20).

The liver and left kidney tissue were stained with hematoxylin and eosin, and analyzed using light microscope with 40X magnification view, for histological changes. The inflammation level of liver tissue was evaluated for portal inflammation, liver inflammation score, liver hydropic change score, liver necrosis, live granuloma, and the inflammation level of kidney tissue were assessed for presence of any inflammation or fibrosis in the kidney tissue and kidney fibrosis score was calculated also.

\section{Statistical Analysis}

Data are expressed as mean $\pm \mathrm{SD}$. The statistical analysis was based on five rats per group and mean values were compared by means of Student's t-test at Pvalue $<0.05$. The Statistical Package of Social Science version 20.0 (SPSS, Chicago, Illinois, USA) was used for data analysis.

\section{Results}

Body weight changes and $\mathrm{Cd}$ concentration in liver and kidney tissues of 10 groups of study have been reported in Table 1. The highest amount of $\mathrm{Cd}$ is seen in liver and kidney tissues of group 5 , receiving $5 \mathrm{mg} \mathrm{Cd} / \mathrm{kg}$ alone $(P<0.001$ and $P=0.04$, respectively). 
Table 1. Mean body weight changes and mean cadmium concentration in the liver and kidney tissues.

\begin{tabular}{|c|c|c|c|c|c|}
\hline Groups & Treatment & $\begin{array}{c}\text { Initial body } \\
\text { weight } \\
\text { mean (g) }\end{array}$ & $\begin{array}{c}\text { Final body } \\
\text { weight } \\
\text { mean }(\mathrm{g})\end{array}$ & $\begin{array}{c}\text { Cd level } \\
\text { in } \\
\text { Liver } \\
(\mu \mathrm{g})\end{array}$ & $\begin{array}{c}\text { Cd level in } \\
\text { Kidney } \\
(\mu \mathrm{g})\end{array}$ \\
\hline Control & & 142 & 196 & 0 & 67 \\
\hline Sham & & 144 & 199 & 0 & 0 \\
\hline 1 & $1 \mathrm{mg} / \mathrm{kg} \mathrm{Cd}+$ tap water & 140 & 173 & 1900 & 3167 \\
\hline 2 & $1 \mathrm{mg} / \mathrm{kg} \mathrm{Cd}+$ supplemented water* & 133 & 189 & 1750 & 2583 \\
\hline 3 & $\begin{array}{c}1 \mathrm{mg} \mathrm{Cd} / \mathrm{kg}+1 \mathrm{mg} \mathrm{Se} / \mathrm{kg}, \text { i.p. }+ \\
\text { tap water }\end{array}$ & 147 & 195 & 1500 & 2167 \\
\hline 4 & $\begin{array}{c}1 \mathrm{mg} \mathrm{Cd} / \mathrm{kg}+1 \mathrm{mg} \mathrm{Se} / \mathrm{kg}, \text { i.p. }+ \\
\text { supplemented water* }\end{array}$ & 147 & 191 & 1373 & 1917 \\
\hline 5 & $5 \mathrm{mg} \mathrm{Cd} / \mathrm{kg}+$ tap water & 135 & 152 & 2750 & 4167 \\
\hline 6 & $5 \mathrm{mg} \mathrm{Cd} / \mathrm{kg}+$ supplemented water* & 142 & 194 & 2167 & 2750 \\
\hline 7 & $\begin{array}{c}5 \mathrm{mg} \mathrm{Cd} / \mathrm{kg}+1 \mathrm{mg} \mathrm{Se} / \mathrm{kg} \mathrm{Se} \text {, i.p. }+ \\
\text { tap water }\end{array}$ & 132 & 183 & 2117 & 3083 \\
\hline 8 & $\begin{array}{c}5 \mathrm{mg} \mathrm{Cd} / \mathrm{kg}+1 \mathrm{mg} \mathrm{Se} / \mathrm{kg}, \text { i.p. }+ \\
\text { supplemented water* }\end{array}$ & 149 & 196 & 1833 & 2083 \\
\hline
\end{tabular}

*supplemented with $10 \mathrm{mg} / \mathrm{l}$ vitamin C.

i.p.: intraperitoneal; Cd: cadmium; Se: Selenium.

Table 2. Different grades of focal (spotty) lytic necrosis, apoptosis, and focal inflammation in the liver tissue.

\begin{tabular}{|c|c|c|c|c|c|c|c|c|c|c|c|}
\hline \multirow{2}{*}{\multicolumn{2}{|c|}{ Grade }} & \multicolumn{10}{|c|}{ Groups } \\
\hline & & \multirow{2}{*}{$\frac{\text { Control }}{5}$} & \multirow{2}{*}{$\begin{array}{c}\text { Sham } \\
4\end{array}$} & \multirow{2}{*}{$\begin{array}{l}1 \\
0\end{array}$} & \multirow{2}{*}{$\begin{array}{l}2 \\
0\end{array}$} & \multirow[b]{2}{*}{1} & \multirow{2}{*}{$\begin{array}{l}4 \\
0\end{array}$} & \multirow{2}{*}{$\begin{array}{l}5 \\
0\end{array}$} & \multirow{2}{*}{$\begin{array}{l}6 \\
0\end{array}$} & \multirow{2}{*}{$\begin{array}{l}7 \\
0\end{array}$} & \multirow{2}{*}{$\begin{array}{l}8 \\
2\end{array}$} \\
\hline & No. & & & & & & & & & & \\
\hline & $\%$ & 30.2 & 57.1 & - & - & 14.3 & - & - & - & - & 28.6 \\
\hline \multirow{2}{*}{ Mild } & No. & 1 & 2 & 1 & 2 & 3 & 2 & 0 & 0 & 2 & 4 \\
\hline & $\%$ & 12.5 & 12.5 & 6.2 & 12.5 & 18.8 & 12.5 & - & - & 12.5 & 25.0 \\
\hline \multirow{2}{*}{ Moderate } & No. & 0 & 0 & 1 & 4 & 1 & 3 & 2 & 5 & 4 & 0 \\
\hline & $\%$ & - & - & 5.0 & 20.0 & 5.0 & 15.0 & 10.0 & 25.0 & 20.0 & - \\
\hline \multirow{2}{*}{ Marked } & No. & 0 & 0 & 4 & 0 & 1 & 1 & 4 & 1 & 0 & 0 \\
\hline & $\%$ & - & - & 36.4 & - & 9.1 & 9.1 & 36.4 & 9.1 & - & - \\
\hline
\end{tabular}

Absent: none, Mild (One focus or less per 10 objectives), Moderate (Two to four foci per 10Xobjectives or five to ten foci per 10Xobjectives), Marked (More than ten foci per 10Xobjectives)

Overall, consumption of supplemented water was $11 \mathrm{mg} /$ animal vitamin $\mathrm{C}$ in group $2(1 \mathrm{mg} / \mathrm{kg} \mathrm{Cd}+$ Tao water), $10.1 \mathrm{mg} /$ animal vitamin $\mathrm{C}$ in group 4 (1 mg $\mathrm{Cd} / \mathrm{kg}+1 \mathrm{mg} \mathrm{Se} / \mathrm{kg}$, i.p. + supplemented water), 9.2 $\mathrm{mg}$ /animal vitamin $\mathrm{C}$ in group $6(5 \mathrm{mg} \mathrm{Cd} / \mathrm{kg}+$ supplemented water), and $10.2 \mathrm{mg} /$ animal vitamin $\mathrm{C}$ in group 8 ( $5 \mathrm{mg} \mathrm{Cd} / \mathrm{kg}+1 \mathrm{mg} \mathrm{Se} / \mathrm{kg}$, i.p. + supplemented water).

Table 2 shows different grades of focal or spotty necrosis in liver tissue in experimental groups. As seen the highest grades were obtained in groups receiving $\mathrm{Cd}$ alone $(P<0.001)$. Vitamin $\mathrm{C}$ and Se could alleviate the necrosis in experimental groups. Table 3 shows different grades of portal infla-mmation in experimental groups. As seen the highest grades were found in groups receiving $\mathrm{Cd}$ alone $(P=0.02)$.

Table 4 shows different grades of liver congestion in experimental groups. As noted, the highest grades were found in groups receiving $\mathrm{Cd}$ alone $(P<0.001)$.

Table 5 shows different grades of liver parenchymal inflammation in experimental groups. As seen the highest grades of inflammation were presented in groups receiving $\mathrm{Cd}$ alone but this difference was not significant $(P=0.65)$.

Different grades of inflammation in kidney tissue of experimental groups, is shown in Table 6. As seen the 
highest grade of inflammation was observed in groups receiving Cadmium alone $(P=0.01)$.

Table 3. Different grades of portal inflammation in the liver tissue.

\begin{tabular}{|c|c|c|c|c|c|c|c|c|c|c|c|}
\hline \multirow{2}{*}{$\begin{array}{c}\text { Portal } \\
\text { Inflammation } \\
\text { Grade }\end{array}$} & & \multicolumn{10}{|c|}{ Groups } \\
\hline & & Control & Sham & 1 & 2 & 3 & 4 & 5 & 6 & 7 & 8 \\
\hline \multirow[b]{2}{*}{ None } & No. & 4 & 3 & 0 & 0 & 1 & 0 & 0 & 0 & 0 & 1 \\
\hline & $\%$ & 20.0 & 60.0 & - & - & 20.0 & - & - & - & - & 20.0 \\
\hline \multirow{2}{*}{ Rare } & No. & 2 & 3 & 1 & 2 & 4 & 3 & 0 & 1 & 2 & 4 \\
\hline & $\%$ & 10.0 & 15.0 & 5.0 & 10.0 & 20.0 & 15.0 & - & 5.0 & 10.0 & 20.0 \\
\hline \multirow{2}{*}{ Mild } & No. & 0 & 0 & 1 & 3 & 1 & 3 & 0 & 3 & 4 & 1 \\
\hline & $\%$ & - & - & 6.2 & 18.8 & 6.2 & 18.8 & - & 18.8 & 25.0 & 6.2 \\
\hline \multirow{2}{*}{ Moderate } & No. & 0 & 0 & 3 & 1 & 0 & 0 & 4 & 2 & 0 & 0 \\
\hline & $\%$ & - & - & 30.0 & 10.0 & - & - & 40.0 & 20.0 & - & - \\
\hline \multirow{2}{*}{ Marked } & No. & 0 & 0 & 1 & 0 & 0 & 0 & 2 & 0 & 0 & 0 \\
\hline & $\%$ & - & - & 33.3 & - & - & - & 66.7 & - & - & - \\
\hline
\end{tabular}

None: No portal inflammation, Rare (scant/ mild inflammation in some portal areas), Mild (mild to moderate inflammation in some/most portal areas), Moderate (moderate inflammation in all portal areas, marked (marked inflammation in all portal areas)

Table 4. Different grades of liver congestion.

\begin{tabular}{|c|c|c|c|c|c|c|c|c|c|c|c|}
\hline \multirow{2}{*}{$\begin{array}{c}\text { Liver } \\
\text { Congestion } \\
\text { Grade }\end{array}$} & & \multicolumn{10}{|c|}{ Groups } \\
\hline & & Control & Sham & 1 & 2 & 3 & 4 & 5 & 6 & 7 & 8 \\
\hline \multirow{2}{*}{ None } & No. & 5 & 2 & 0 & 0 & 0 & 0 & 0 & 0 & 0 & 3 \\
\hline & $\%$ & - & - & - & - & - & - & - & - & - & - \\
\hline \multirow{2}{*}{ Rare } & No. & 1 & 4 & 0 & 0 & 2 & 2 & 0 & 0 & 2 & 3 \\
\hline & $\%$ & 15.4 & 30.8 & - & - & 15.4 & 15.4 & - & - & 15.4 & 23.1 \\
\hline \multirow{2}{*}{ Mild } & No. & 0 & 0 & 1 & 4 & 3 & 2 & 0 & 4 & 3 & 0 \\
\hline & $\%$ & - & - & 5.9 & 23.5 & 17.6 & 11.8 & - & 23.5 & 17.6 & - \\
\hline \multirow{2}{*}{ Modreate } & No. & 0 & 0 & 3 & 2 & 1 & 2 & 3 & 2 & 1 & 0 \\
\hline & $\%$ & - & - & 21.4 & 14.3 & 7.1 & 14.3 & 21.4 & 14.3 & 7.1 & - \\
\hline \multirow{2}{*}{ Marked } & No. & 0 & 0 & 2 & 0 & 0 & 0 & 3 & 0 & 0 & 0 \\
\hline & $\%$ & - & - & 40.0 & - & - & - & 60.0 & - & - & - \\
\hline
\end{tabular}

None: no sinusoidal congestion, Rare (Rare foci), Mild (congestion in one third of liver parenchyma), Moderate (between one third to two third of liver parenchyma), Marked (more than two third of liver parenchyma)

Table 5. Different grades of liver parenchymal inflammation (confluent necrosis) *.

\begin{tabular}{|c|c|c|c|c|c|c|c|c|c|c|c|}
\hline \multirow{2}{*}{$\begin{array}{c}\text { Liver } \\
\text { Parenchyma } \\
\text { Inflammation } \\
\text { Grade }\end{array}$} & & \multicolumn{10}{|c|}{ Groups } \\
\hline & & Control & Sham & 1 & 2 & 3 & 4 & 5 & 6 & 7 & 8 \\
\hline \multirow[b]{2}{*}{ Absent } & No. & 6 & 5 & 1 & 2 & 2 & 3 & 0 & 5 & 5 & 5 \\
\hline & $\%$ & 7.1 & 17.9 & 3.6 & 7.1 & 7.1 & 10.7 & - & 17.9 & 17.9 & 17.9 \\
\hline \multirow{2}{*}{ Rare } & No. & 0 & 1 & 3 & 2 & 3 & 3 & 3 & 1 & 1 & 1 \\
\hline & $\%$ & - & 5.6 & 16.7 & 11.1 & 16.7 & 16.7 & 16.7 & 5.6 & 5.6 & 5.6 \\
\hline \multirow{2}{*}{ Mild } & No. & 0 & 0 & 2 & 2 & 1 & 0 & 3 & 0 & 0 & 0 \\
\hline & $\%$ & - & - & 25.0 & 25.0 & 12.5 & - & 37.5 & - & - & - \\
\hline
\end{tabular}




\begin{tabular}{|c|c|c|c|c|c|c|c|c|c|c|c|}
\hline $\begin{array}{c}\text { Liver } \\
\text { Parenchyma } \\
\text { Inflammation } \\
\begin{array}{c}\text { Grade } \\
\text { Moderate to } \\
\text { severe }\end{array}\end{array}$ & 0 & Control & Sham & 1 & 2 & 3 & 4 & 5 & 6 & 7 & 8 \\
\hline
\end{tabular}

Absent: 0, Rare (Focal confluent necrosis), Mild (Zone 3 necrosis in some areas), Moderate to severe (the spectrum from more diffuse and severe necrosis/ inflammation to panacinar necrosis)

* we did not have the following items (more severe inflammation), you can add a row with 0 number or percent: Zone 3 necrosis in most areas, Zone 3 necrosis 1 occasional portal-central (P-C) bridging, Zone 3 necrosis 1 multiple P-C bridging, and Panacinar or multiacinar necrosis.

Table 6. Different grades of inflammation in the kidney tissue.

\begin{tabular}{|c|c|c|c|c|c|c|c|c|c|c|c|}
\hline \multirow{2}{*}{ Grade } & & \multicolumn{10}{|c|}{ Groups } \\
\hline & & Control & Sham & 1 & 2 & 3 & 4 & 5 & 6 & 7 & 8 \\
\hline \multirow{2}{*}{ Rare } & No. & 4 & 5 & 0 & 1 & 2 & 0 & 0 & 1 & 2 & 4 \\
\hline & $\%$ & 6.7 & 33.3 & - & 6.7 & 13.3 & - & - & 6.7 & 13.3 & 26.7 \\
\hline \multirow{2}{*}{ Mild } & No. & 2 & 1 & 2 & 3 & 1 & 4 & 1 & 3 & 3 & 2 \\
\hline & $\%$ & 5 & 5.0 & 10.0 & 15.0 & 5.0 & 20.0 & 5.0 & 15.0 & 15.0 & 10.0 \\
\hline \multirow{2}{*}{ Moderate } & No. & 0 & 0 & 3 & 2 & 3 & 1 & 2 & 2 & 1 & 0 \\
\hline & $\%$ & - & - & 21.4 & 14.3 & 21.4 & 7.1 & 14.3 & 14.3 & 7.1 & - \\
\hline \multirow{2}{*}{ Marked } & No. & 0 & 0 & 1 & 0 & 0 & 1 & 3 & 0 & 0 & 0 \\
\hline & $\%$ & - & - & 20.0 & - & - & 20.0 & 60.0 & - & - & - \\
\hline
\end{tabular}

Rare: in rare foci, Mild (inflammatory cell infiltration was identified in one third of kidney parenchyma), Moderate (In one third to two third of kidney parenchyma), Marked (More than two third of the kidney parenchyma was involved by inflammatory cell infiltration)

\section{Discussion}

Chronic exposure to $\mathrm{Cd}$, may lead to nephrotoxicity, hepatotoxicity, damages to nervous system, immune and endocrine system, and finally cancer in human beings (21-22) Moreover, accumulation of heavy metals may affect the function of cells' proteins which can lead to organ dysfunction (15). Present study confirmed Cd-induced inflammation, in kidney and liver of rats, after 28 days exposure to 1 or $5 \mathrm{mg} \mathrm{Cd} / \mathrm{kg}$, which adjusted by combination of Vitamin $\mathrm{C}$ and Se. This adjustment prevents $\mathrm{Cd}$ induced weight loss, significantly.

Omonkhua et al. Study showed that low dosages of $\mathrm{Cd}$ (1 to $3 \mu \mathrm{g} / \mathrm{kg} \mathrm{BW}$ ), for four weeks, induce $\mathrm{Cd}$ toxicity in rats, with or without vitamin $\mathrm{C}$ supplementation. Serum alkaline phosphatase had increased significantly in all the groups, even in groups supplemented with vitamin C. But, for some other evaluated parameters, such as serum calcium and bone protein concentration, vitamin $\mathrm{C}$ prevented the effects of $\mathrm{Cd}$ on the treated rats, indicating that vitamin $\mathrm{C}$ may have protective effect, even against low dosage of $\mathrm{Cd}$ (13).

In a study, vitamin $\mathrm{C}$ supplement was used for adjustment $\mathrm{Cd}$ toxicity. In this study, rats were fed with supplemented food with $10 \mathrm{mg} / \mathrm{kg}$ of $\mathrm{Cd}$, equivalent with $1.0-1.2 \mathrm{mg} \mathrm{Cd} / \mathrm{kg}$ in 28 days. Vitamin $\mathrm{C}$ was added to one of the experimental group's drinking water. The result of this study showed less concentration of $\mathrm{Cd}$ in liver, kidneys, testis and muscles in this group. Thus, this group had better weight gain at the end of the experimental period (23) but mentioned study did not evaluate the prophylactic effects of vitamin $\mathrm{C}$ on high dosages of $\mathrm{Cd}$, which was evaluated in present study.

El-Sharaky et al. studied on the adjustment of $\mathrm{Cd}$ toxicity in rat by using Se. In this study intraperitoneal injection of $2 \mathrm{mg} / \mathrm{kg} \mathrm{Cd}$ for 10 days leads to lipid peroxidation in rat's kidneys. Using $1 \mathrm{mg} / \mathrm{kg}$ Se twice a day protected the kidney tissue via increasing the antioxidant effect (8). By using $1 \mathrm{mg} / \mathrm{kg} \mathrm{Se}$, increase of antioxidant effect leads to decrease hepatotoxicity of $\mathrm{Cd}$ (21).

In a study of protective effect of vitamin $\mathrm{E}$ and aspirin towards the cell toxicity, Mattie et al. confirmed that these agents exert their protective effect via antioxidation (15). Administration of intraperitoneal injection of $\mathrm{CdCl}(2)$ with $0.4 \mathrm{mg} / \mathrm{kg}$ concentration caused the changes in antioxidation defense system. To adjust this effect, intramuscular injection of $10 \mathrm{mg} / \mathrm{kg}$ coenzyme Q (10) with $20 \mathrm{IU} / \mathrm{kg}$ vitamin E were used. Interestingly, these results indicated that coenzyme Q (10) and vitamin E could reduce the toxicity of high dosage of Cd (16). Furthermore, many other substances 
such as, vitamin E $100 \mathrm{mg} / \mathrm{kg}$ and beta-carotene 10 $\mathrm{mg} / \mathrm{kg}$ independently or in combination have been used in rats via gavages to adjust the toxic effect of $5 \mathrm{mg} / \mathrm{kg}$ of $\mathrm{CdCl}(2)$; as a result, increase in level of liver enzymes, creatinine, urea, bilirubin and decrease in hemoglobin and albumin have been seen which this adverse effect reduced by combination of alphatocopherol and beta-carotene (19).

Beneficial effects of vitamin $\mathrm{C}$ were evaluated in several studies, to reduce the $\mathrm{Cd}$ induced toxicity. Present study revealed that vitamin $\mathrm{C}$ supplement caused decrease in the $\mathrm{Cd}$ content of liver and kidney, especially vitamin $\mathrm{C}$ in combination with $\mathrm{Se}$, reduced $\mathrm{Cd}$ content, more than distinct administration of Se or vitamin $\mathrm{C}$. In a study on Cd-induced toxicity, administration of vitamin $\mathrm{C}$ was led to decrease in lipid peroxidation and this study showed that vitamin $\mathrm{C}$ could play protective role against the testicular steroidogenesis and germ cell death (24). In Grosicki study, $1-1.2 \mathrm{mg} / \mathrm{kg} \mathrm{CdCl}(2)$ daily dosage were administrated for 28 days, in order to pose the rats in combination with $1.5 \mathrm{mg} / \mathrm{L}$ vitamin $\mathrm{C}$ via gavage. Eventually, accumulation of $\mathrm{Cd}$ in liver, kidney, testes, and muscles has been reduced by using vitamin $\mathrm{C}$ and the treated group had appropriate weight gain during the experiment (23). Additionally, in another study of vitamin $\mathrm{C}$ was used to prevent the lethality effect of acute Cd toxicity; administration of $25 \mu \mathrm{mol} / \mathrm{kg}$ s.c of $\mathrm{CdCl}(2)$ after 72 hours cause $93 \%$ mortality in rats which in comparison with other treated groups with vitamin $\mathrm{C}(2 \mathrm{~g} / \mathrm{kg}$ s.c.) the killing effect was almost inhibited (21).

In present study, a significant decrease was observed in Cd level of Se treated groups, especially when Se was administered in combination with vitamin C. El-Sharaky et al. showed that intraperitoneal administration of $2 \mathrm{mg} / \mathrm{kg} \mathrm{CdCl}(2)$ in 10 days led to lipid peroxidation in kidneys of the animals; remarkably, administration of $1 \mathrm{mg} / \mathrm{kg}$ of Se, twice a day, resulted in protection of kidney and decrease in hepatotoxicity by increase in activity of antioxidant enzymes (8). In another study administration of $1 \mathrm{mg}$ of $\mathrm{CdCl}(2)$ in a guinea pig per day via drinking water has been evaluated for lipid peroxidation. After following the experiment, increase in lipid peroxidation in kidney and liver has been demonstrated. However, this effect was reduced after administration of daily $100 \mathrm{mg}$ of vitamin C. It is suggested that usefulness of vitamin $\mathrm{C}$, is dependent on amount of accumulated $\mathrm{Cd}$ (25), but beneficial effects of Se have not been reported, as a dependent effect with $\mathrm{Cd}$ accumulated levels. In addition, recent study reported $\mathrm{Se}$ as a chemopreventive and chemotherapeutic agents for human cancers and daily supplement of Se has been recommended (26). Therefore, in this study, new combination of potent prophylactic agents were studied (vitamin $\mathrm{C}$ and $\mathrm{Se}$ ), which do not have major side effects in prolonged daily usage.

\section{Conclusion}

Based on the findings of this study, $\mathrm{CdCl}$ accumulates and influences on liver and kidney tissues pathologically and by using supplements such as vitamin $\mathrm{C}$ and $\mathrm{Se}$, these effects can be subsided. In future clinical trials on humans, toxicity of this heavy metal can be evaluated with the addition of supplements containing Se and vitamin C in daily drink and food of workers of many industries such as battery and paint manufacturing, and in case of similar results in human, by this way, by decrease of $\mathrm{Cd}$ toxicity complications, national health costs will be reduced; Vitamin $\mathrm{C}$ and $\mathrm{Se}$ are existed in a common daily drink, such as non-alcoholic beer.

\section{Acknowledgements}

This research has been supported by Students' Scientific Research Center of Tehran University of Medical Science.

\section{Conflict of Interest}

The authors had no conflict of interest to report.

\section{Funding Support}

This research has been supported by Students' Scientific Research Center of Tehran University of Medical Science.

\section{References}

1. Lemen RA, Lee JS, Wagoner JK, Blejer HP. Cancer Mortality among Cadmium Production Workers. Ann N Y Acad Sci. 1976;271(1):273-9. [DOI:10.1111/j.1749-6632.1976.tb23122.x] [PMID]

2. Zamani M, Mortazavi S, Aligholi M, Mahmoud Janlou $\mathrm{H}$, Khodi Aghmiuni S, Pormasjedi-Meibod M, et al. Native Bacterial Mixed Culture: A Proportionate Solution for Refinery and Petrochemical Wastewaters. Thrita J Med Sci. 2012;1(4):149-54. [DOI:10.5812/thrita.7278]

3. Khalil M, Furness DN, Zholobenko V, Hoole D. Effect of tapeworm parasitisation on cadmium toxicity in the bioindicator copepod, $<\mathrm{i}>$ Cyclops strenuus. Ecol Indic. 2014;37:21-6. [DOI:10.1016/i.ecolind.2013.09.033]

4. Unsal V, Dalkıran T, Çiçek M, Kölükçü E. The Role of Natural Antioxidants Against Reactive Oxygen Species Produced by Cadmium Toxicity: A Review. Adv Pharm Bull. 2020 2020/2/18;10(2):184-202. [DOI:10.34172/apb.2020.023] [PMID] [PMCID]

5. Jemai H, Messaoudi I, Chaouch A, Kerkeni A. Protective effect of zinc supplementation on blood antioxidant defense system in rats exposed to cadmium. J Trace Elem Med Biol. 2007;21(4):269-73. [DOI:10.1016/i.jtemb.2007.08.001] [PMID]

6. Genchi G, Sinicropi MS, Lauria G, Carocci A, Catalano A. The Effects of Cadmium Toxicity. Int J 
Environ Res Public Health. 2020;17(11):3782. [DOI:10.3390/ijerph17113782] [PMID] [PMCID]

7. Satarug S. Dietary Cadmium Intake and Its Effects on Kidneys. Toxics. 2018;6(1):15.

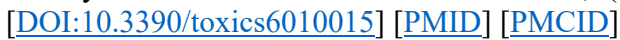

8. El-Sharaky A, Newairy A, Badreldeen M, Eweda S, Sheweita S. Protective role of selenium against renal toxicity induced by cadmium in rats. Toxicology. 2007;235(3):185-93. [DOI:10.1016/j.tox.2007.03.014] [PMID]

9. Morales A, Vicente-Sanchez C, Sandoval J, Egido J, Mayoral $\mathrm{P}$, Arévalo $\mathrm{M}$, et al. Protective effect of quercetin on experimental chronic cadmium nephrotoxicity in rats is based on its antioxidant properties. Food Chem Toxicol. 2006;44(12):2092100. [DOI:10.1016/j.fct.2006.07.012] [PMID]

10. Groten J, Koeman J, Van Nesselrooij J, Luten J, van Vlissingen JF, Stenhuis W, et al. Comparison of renal toxicity after long-term oral administration of cadmium chloride and cadmium-metallothionein in rats. Fundam Appl Toxicol. 1994;23(4):544-52. [DOI:10.1006/faat.1994.1139] [PMID]

11. Müller L, Ohnesorge FK. Cadmium-induced alteration of the energy level in isolated hepatocytes. Toxicology. 1984;31(3):297-306.

[DOI:10.1016/0300483X(84)90110-0]

12. Jeong S-H, Habeebu SS, Klaassen CD. Cadmium decreases gap junctional intercellular communication in mouse liver. Toxicol Sci. 2000;57(1):156-66. [DOI:10.1093/toxsci/57.1.156] [PMID]

13. Omonkhua A, Obi F. Effects of Vitamin C on Kidney and Bone of Rats Exposed to Low Doses of Cadmium. Nigerian J Basic Appl Sci. 2013;20(4):297-304.

14. Acharya UR, Mishra M, Patro J, Panda MK. Effect of vitamins $\mathrm{C}$ and $\mathrm{E}$ on spermatogenesis in mice exposed to cadmium. Reprod Toxicol. 2008;25(1):84-8. [DOI:10.1016/j.reprotox.2007.10.004] [PMID]

15. Mattie MD, Freedman JH. Protective effects of aspirin and vitamin E ( $\alpha$-tocopherol) against copper-and cadmium-induced toxicity. Biochem Biophys Res Commun. [DOI:10.1006/bbrc.2001.5259] [PMID]

16. Ognjanović BI, Marković SD, Pavlović SZ, Žikić RV, Štajn AŠ, Saičić ZS. Combined effects of coenzyme $\mathrm{Q}<\mathrm{sub}>10$ and Vitamin $\mathrm{E}$ in cadmium induced alterations of antioxidant defense system in the rat heart. Environ Toxicol Pharmacol. 2006;22(2):219-24. [DOI:10.1016/j.etap.2006.03.008] [PMID]
17. El-Demerdash FM, Yousef MI, Kedwany FS, Baghdadi HH. Cadmium-induced changes in lipid peroxidation, blood hematology, biochemical parameters and semen quality of male rats: protective role of vitamin $\mathrm{E}$ and $\beta$-carotene. Food Chem Toxicol. 2004;42(10):1563-71. [DOI:10.1016/j.fct.2004.05.001] [PMID]

18. Antosiewicz DM, Hennig J. Overexpression of $<\mathrm{i}>$ LCT1 in tobacco enhances the protective action of calcium against cadmium toxicity. Environ Pollut. 2004;129(2):237-45.

[DOI:10.1016/j.envpol.2003.10.025] [PMID]

19. Rafati-Rahimzadeh M, Rafati-Rahimzadeh M, Kazemi S, Moghadamnia A. Cadmium toxicity and treatment: An update. Caspian J Intern Med. [Review Article]. 2017;8(3):135-45.

20. Shirley R, Benne E, Miller E. Cadmium in biological materials and foods. Anal Chem. 1949;21(2):300-3. [DOI:10.1021/ac60026a018]

21. Newairy A, El-Sharaky A, Badreldeen M, Eweda S, Sheweita S. The hepatoprotective effects of selenium against cadmium toxicity in rats. Toxicology. 2007;242(1):23-30. [DOI:10.1016/j.tox.2007.09.001] [PMID]

22. Hartwig A. Cadmium and Cancer. Cadmium: From Toxicity to Essentiality: Springer; 2013. p. 491-507. [DOI:10.1007/978-94-007-5179-8 15] [PMID]

23. Grosicki A. Influence of vitamin $\mathrm{C}$ on cadmium absorption and distribution in rats. J Trace Elem Med Biol. 2004;18(2):183-7. [DOI:10.1016/j.jtemb.2004.06.003] [PMID]

24. Sen Gupta R, Kim J, Gomes C, Oh S, Park J, Im W-B, et al. Effect of ascorbic acid supplementation on testicular steroidogenesis and germ cell death in cadmium-treated male rats. Mol Cell Endocrinol. 2004;221(1):57-66. [DOI:10.1016/j.mce.2004.03.012] [PMID]

25. Hudecova A, Ginter E. The influence of ascorbic acid on lipid peroxidation in guinea pigs intoxicated with cadmium. Food Chem Toxicol. 1992;30(12):1011-3. [DOI:10.1016/0278-6915(92)90111-W]

26. Feng Y, Su J, Zhao Z, Zheng W, Wu H, Zhang Y, et al. Differential effects of amino acid surface decoration on the anticancer efficacy of selenium nanoparticles. Dalton Trans. [10.1039/C3DT52468J]. 2014. [DOI:10.1039/C3DT52468J] [PMID] 